Višnja G R A B O V A C (Filozofski fakultet Sveučilišta u Zagrebu, Odsjek za indologiju i dalekoistočne studije) vgrabova@ffzg.hr

\title{
BUDDHA U PRVOM I TREĆEM PRIPOVJEDNOM LICU ${ }^{1}$
}

Primljeno: 7. 1. 2020.

UDK: 821.211.09:24

Pripovijesti o Buddhinim prijašnjim egzistencijama nazivaju se đātakama i u njima se prati put Bodhisatte, odnosno budućega Buddhe koji, neprestano se rađajući i umirući, prelazi iz jedne egzistencije u drugu. Svrha je rada pokazati na koji način strukturom đātake utvrđena izmjena pripovjednih lica istovremeno omogućuje i poistovjećivanje i razlikovanje pripovjedača Buddhe i protagonista đātake Bodhisatte. Radom se nastoji i ukazati na osobitosti te buddhističke književne vrste te približiti sadržaj đātaka domaćim čitateljima.

Ključne riječi: pripovjedno lice, đātaka, Bodhisatta, Buddha, buddhistička književnost, buddhistički nauk

\section{UVOD}

U okvirima buddhističke književnosti, doktrine i vjerovanja životopis Gotame Buddhe započinje mnogo prije negoli je rođen u obitelji kralja Suddhodane i kraljice Māye. ${ }^{2}$ Životopis kojim su obuhvaćene i prijašnje Buddhine egzistencije, a u kojima se on naziva Bodhisatta (skt. Bodhisattva), započinje u dalekoj prošlosti kada se kao isposnik Sumedha zavjetovao pred ondašnjim buddhom Dīpańkarom da će postići Probuđenje te od njega dobio potvrdu da ce to zaista i ostvariti. Upravo je u tome trenutku Sumedha postao Bodhisatta, odnosno bice predodređeno za Probuđenje ili biće na putu prema Probuđenju. Pripovijesti o Buddhinim prijašnjim egzistencijama

${ }^{1}$ Rad je proširena verzija izlaganja održanoga na znanstvenome skupu Zadarski filološki dani 8 (Zadar, 8-9. studenoga 2019).

${ }^{2} \mathrm{U}$ ovome se radu rabe pālijske inačice imena i pojmova s obzirom na to da je istraživanje temeljeno na đātakama sačuvanim na jeziku koji se naziva pāli. Uz pojedine će se riječi, gdje će se to smatrati prikladnim, u zagradi dati i njihova sanskrtska inačica (skt.). 
nazivaju se đātakama i u njima se prati put Bodhisatte ili budućega Gotame Buddhe koji, neprestano se rađajući i umirući, prelazi iz jedne egzistencije u drugu. $\mathrm{Na}$ tome se dugom putu usavršava u vrlinama i napreduje prema svojoj posljednjoj egzistenciji u kojoj ce postati Probuđeni (Buddha). Theravādska tradicija ${ }^{3}$ bilježi 547 takvih pripovijesti koje je, prema predaji, iznio sam Buddha. ${ }^{4}$ One su objedinjene u Đätakațthakathāvannani (dalje ĐA), komentaru uz theravādsku kanonsku knjigu Đātaka, a svoj su konačni oblik stekle vjerojatno oko 5. stoljeća. ${ }^{5}$ Ipak, uklesani natpisi s naslovima pojedinih đātaka kao i reljefni prikazi njihova sadržaja datirani u 3. stoljeće pr. Kr. pokazuju da su đātake postale popularne i općepoznate mnogo ranije. Upadljivo svjetovna narav tih pripovijesti, a koje se po svome sadržaju mogu podijeliti na priče s moralnom poukom, basne, anegdote i bajke, navela je mnoge autore da zaključe kako su bile sastavljane i prenošene kao sredstvo poučavanja laičkih sljedbenika, ali narativni okvir pripovijesti objedinjenih u ĐA-i donekle opovrgava takvo stajalište. ${ }^{6}$ Ipak, sasvim je sigurno da mnoge pripovijesti u svome izvornome obliku nisu bile buddhističke i da su postojale i kolale među narodom i prije pojave buddhizma, pa se neke od njih mogu susresti i u drugim djelima indijske pripovjedne književnosti. ${ }^{7}$ Buddhističkima su postale tek poistovjećivanjem nekoga od likova s Bodhisattom, a tako preinačene služile su, između ostaloga, i kao važno sredstvo širenja, popularizacije i udomaćivanja buddhizma na novim područjima. ${ }^{8}$ Iako brojnost đātaka, raznolikost motiva i književnih vrsta koje su njima obuhvaćene, kao i njihovo povijesno, vjersko i antropološko-etnološko značenje nude mnoštvo polazišnih točaka odnosno mogućnosti za njihovu analizu i interpretaciju, u ovome će se radu pažnja posvetiti njihovoj strukturi. Točnije, nastojat će se pokazati na koji način strukturom dātake utvrđena izmjena pripovijedanja u

3 Theravāda (dosl. učenje/nauk/doktrina ili govor starješina) najstarija je postojeća buddhistička škola. Danas je prisutna u Šri Lanki, Tajlandu, Burmi, Kambodži i Laosu. Kanon te škole, sačuvan na pāliju i zapisan na Šri Lanki početkom nove ere, naziva se Tipițaka (dosl. Tri košare). Opširnije u Katičić 1973: 153-157.

${ }^{4}$ Sustavan pregled povijesnoga razvoja i opširniji opis temeljnih obilježja te književne vrste nudi Appleton 2010.

${ }^{5}$ Jātakatthavaṇnanā. Kritičko je izdanje u šest svezaka priredio Viggo Fausbøll, a objavljeno je između 1877. i 1896. godine. Prijevod dātaka sadržanih u ĐA-i dostupan je na mrežnoj stranici https://www.sacred-texts.com/bud/index.htm (8. listopada 2020).

${ }^{6}$ Naime, iako postoje i đātake upućene laicima, te su pripovijesti najvećim dijelom upućene upravo redovnicima, bilo da je riječ o grupi neimenovanih redovnika ili o imenovanim pojedincima redovničke zajednice. V. i Appleton 2015: 11.

${ }^{7}$ Olivelle 2009: xi; Katičić 1973: 165-167; Rhys Davids 1878: xxvii-xlvi.

${ }^{8}$ V. Appleton 2007. 
prvom i trećem licu istovremeno omogućuje poistovjećivanje i razlikovanje pripovjedača Buddhe i protagonista đātake Bodhisatte. Pri tome će se autorica ponajviše oslanjati na radove Sare Shaw (2010) i Naomi Appleton (2007, 2015), nastojeći na jednom mjestu sistematizirati, oprimjeriti, a ponegdje i razjasniti pojedine njihove zaključke i opažanja. Autorica će također pokušati pokazati da struktura đātaka omogućuje i tumačenje prema kojem one nisu isključivo pripovijesti o Bodhisattinim prijašnjim egzistencijama, već da, kao i bajke, nude model za rješavanje svakodnevnih problema u kojima se zatječu i "obična" bića. Iako je poteškoća, a koja se javlja pri pokušaju izmirenja buddhističkoga nauka o nepostojanju trajnoga sopstva i ideje o neprekidnom prerađanju, već odavno prepoznata, u radu će se pokušati pokazati i na koji način izmjena pripovjednih lica ilustrira, ali i možebitno pomiruje ta važna buddhistička učenja. Također, svrha je rada pružiti domaćim čitateljima, koliko je to moguće u okviru jednoga rada, barem djelomičan uvid u sadržaj tih iznimno slikovitih i raznolikih pripovijesti.

\section{STRUKTURA ĐĀTAKA}

Đātake imaju karakterističnu i strogo utvrđenu strukturu. Na samome je početku "priča iz sadašnjosti" (paccuppanavatthu) u kojoj se iznosi povod za Buddhino izlaganje neke od svojih prijašnjih egzistencija. Slijedi potom "priča iz prošlosti" (atìtavatthu) ili đātaka u užem smislu u koju su uklopljeni stihovi ( $(a \bar{a} t h \bar{a})$, a na samome je kraju zaključak (samodhāna) u kojem Buddha likove iz priče o prošlosti poistovjećuje s likovima iz priče o sadašnjosti. Valja naglasiti da se upravo tom strukturom razlikuju od ostalih buddhističkih književnih rodova i drugih pripovijesti o prijašnjim egzistencijama. ${ }^{9}$

\subsection{PRIČA IZ SADAŠNJOSTI}

Priča iz sadašnjosti donosi povod za Buddhino izlaganje nekog događaja iz svojih prijašnjih egzistencija, a prethodi joj stih kojim se najavljuje sadržaj priče iz prošlosti. Velik broj đātaka započinje opisom razgovora među re-

${ }^{9}$ Naime, u pālijskim se kanonskim tekstovima, kao i drugim djelima buddhističke književnosti ponekad susreću pripovijesti koje opisuju Buddhine ili prijašnje egzistencije drugih osoba. Budući da im ponekad nedostaje priča iz sadašnjosti, ponekad zaključak, a u nekima se uopće ne javlja lik Bodhisatte, ne smatraju se đātakama u strogom smislu. 
dovnicima, a koji za predmet ima neki problem ili nesuglasicu u redovničkoj zajednici, nečije plemenito, uzorno ili pak neprikladno ili neuobičajeno ponašanje. Buddha će na molbu redovnika riješiti ili rasvijetliti situaciju ne odbacujući pritom ni jedan problem kao nedostojan njegova uzvišenoga statusa ili mudrosti. Tako je, primjerice, dātaku broj 2 ispričao kao odgovor na manjak ustrajnosti primijećen kod jednoga redovnika, dātakom br. 27 objasnio je razlog čvrstoga prijateljstva između jednoga redovnika i laika, a đātaku br. 159 Buddha je ispričao redovniku koji je priznao da je "zgriješio mišlju” ugledavši lijepu ženu. ${ }^{10}$ Đātakom br. 211 Buddha je objasnio redovnicima zašto jedan od njih nije bio u stanju izreći suvislu rečenicu u prisutnosti više od dvoje ljudi, dok je đātaku br. 276 uputio redovniku koji je namjerno ubio divlju patku. Čak i tako letimičan prikaz povoda za iznošenje đātaka pokazuje, vjerujem, raznolikost i neiscrpnost mogućih situacija do čijih je razjašnjenja i rješenja dovelo Buddhino prepričavanje događaja iz njegovih prijašnjih egzistencija.

\subsection{PRIČA IZ PROŠLOSTI ILI ĐĀTAKA U UŽEM SMISLU}

Priča iz prošlosti ili đātaka u užem smislu Buddhin je odgovor na molbu redovnika da saznaju uzrok pojedinog događaja, problema ili nečijega ponašanja. Protagonist je najvećega broja đātaka Bodhisatta, odnosno Buddha u nekoj od svojih prijašnjih egzistencija, ali postoje i đātake u kojima Bodhisatta ima sasvim beznačajnu ulogu. Takva je, primjerice, đātaka br. 18 u kojoj je Bodhisatta, rođen kao svojevrsni šumski vilenjak ili duh koji boravi u stablu, tek puki promatrač događaja koji u nekoliko stihova ističe lošu karmičku posljedicu koja proizlazi iz ubijanja životinja. Iako navedeni primjer nagovještava raznolikost mogućih rođenja, ona je ipak donekle ograničena. U uvodu se ĐA-e navodi da se na Probuđenje zavjetovana bića ne mogu roditi u paklu, u prostoru između svjetova, ne mogu se roditi kao asure ${ }^{11}$ ili bića mučena glađu i žeđi, a ne rađaju se ni kao male životinje. Nadalje, ako su rođena kao ljudi, onda takva bića nisu rođena slijepa, gluha, ali ni kao žene, hermafroditi ili bespolci. Iako se mogu roditi u nebesima, ne rađaju se kao nesvjesni (asañña) nebesnici. Naglašava se također da su bića na putu prema Probuđenju oslobođena pogrešnih stavova i djela koja donose smrt te da su uvijek povezana s čistim djelovanjem jer razumiju "karmički

\footnotetext{
${ }^{10}$ Redni broj đātaka slijedi Fausböllovo izdanje.

${ }^{11}$ Nebeska bića, najčešće zastrašujuća.
} 
mehanizam". Takva bića uvijek teže odricanju od svjetovnoga za koje nisu vezana (ĐA 1. 44-45).

Navedena pravila ipak nisu stroga kakvima se čine. Primjerice, Bodhisatta se u pojedinim đātakama pojavljuje kao zec, iguana i riba, pa je, kako ističe i Appleton, odgovor na pitanje što se točno podrazumijeva pod "malom” životinjom nejasan (Appleton 2010: 94). Čak se i u dātakama ĐA-e dosljedno primjenjivano pravilo prema kojem se Bodhisatta nikada ne rađa u tijelu žene krši u jednoj kasnijoj zbirci đātaka (Appleton 2010: 77). Ipak, u najvećem se broju đātaka Bodhisatta rađa kao muškarac, "veća” životinja ili ptica. Kao primjeri životinja i ptica u čijem se obliku Bodhisatta rodio mogu se navesti zec (br. 316), riba (br. 236), iguana (br. 141), žaba (br. 239), slon (br. 514), majmun (br. 20 i 222), bik (br. 29 i 278), jelen (br. 11, 12 i 21), vrana (br. 140), golub (br. 42 i 274), strvinar (br. 164), labud (br. 502), guska (br. 476), štakor (br. 128 i 129) i zmija (br. 506). "Ljudska rođenja" nisu ništa manje raznolika, pa se Bodhisatta pojavljuje kao isposnik (br. 17, 43 i 94), kralj (br. 9, 14 i 95), ministar (br. 120 i 473), kraljev sin (br. 7, 151, 160 i 547), pljačkaš i ljubavnik (br. 279 i 318), kockar (br. 62), brāhamaṇ (87, 99 i 174), trgovac (br. 44 i 54), siromah (br. 201), prosjak (br. 212), učitelj (br. 64, 203 i 252), stolar (br. 466), svirač u školjku (br. 60), bubnjar (br. 59), liječnik (br. 69), brižan otac (br. 477), ćandala, odnosno pripadnik najnižega društvenog staleža (br. 497), nadničar (br. 421) i tako dalje.

Bodhisattini postupci uglavnom su egzemplarni. U uvodu se ĐA-e navodi kako su Bodhisattina djela uvijek usmjerena prema postizanju savršenstva (pāramī, skt.pāramitā $)^{12}$ u velikodušnosti, ćudorednosti, odricanju od svjetovnoga, mudrosti, trudu, strpljenju, iskrenosti, odlučnosti, dobronamjernosti i smirenosti. Ta su savršenstva shvaćena kao glavni preduvjet za postizanje Probuđenja (ĐA 1.44-45). Ipak, treba naglasiti da se u najvećem broju đātaka savršenstva ne imenuju izričito te da se mnoge po svome sadržaju ne odnose ni na jedno, dok se pojedine pak odnose na više njih. Pokušaj sistematizacije i stavljanja jasnoga naglaska na savršenstva vidljiv je tek u posljednjih deset đātaka ĐA-e od kojih svaka za svrhu ima ilustrirati jedno savršenstvo. Posljednja i ujedno najpoznatija među buddhistima, Vessantarađātaka (br. 547), posvećena je ultimativnom savršenstvu u darežljivosti. U toj dātaki Bodhisatta, rođen kao princ Vessantara, smireno daruje svoje kraljevstvo i bogatstvo, pa čak i ženu i djecu. U pojedinim je dātakama Bodhisatta spreman odreći se čak i vlastitoga života. Tako se, primjerice, u đātaki br. 316 Bodhisatta, rođen kao zec, baca u vatru kako bi dao svoje meso gladnom

12 Opširnije u Dayal 1970: 165-167. 
isposniku, a u đātaki br. 12, rođen kao jelen Nigrodha, spremno nudi svoj život kuharu nekog kralja u zamjenu za život noseće košute. Kao primjeri brojnih i manje ekstremnih đātaka u kojima Bodhisatta svojim postupcima ukazuje na ispravan način djelovanja i potvrđuje buddhističke vrline, ali i vrline koje bismo mogli nazvati općeljudskima, mogu se navesti npr. đātaka br. 318 koja veliča prijateljstvo, br. 164 u kojoj se ističe važnost brige za roditelje, br. $474 \mathrm{u}$ kojoj se ilustrira dobrobit proistekla iz poštivanja učitelja, br. 169 koja potiče na milosrđe i br. 203 u kojoj Bodhisatta poučava kako se s osjećajem dobronamjernosti odnositi spram svih bića.

Ipak, usprkos brojnosti đātaka u kojima je Bodhisatta utjelovljenje ispravnoga djelovanja i mudrosti, postoje i one u kojima krši propise i djeluje suprotno buddhističkom shvaćanju ispravnoga djelovanja. Tako primjerice u đātaki br. 208, rođen kao majmun, laže krokodilu koji želi pojesti njegovo srce da ga je ostavio na grani neke smokve, kršeći time propis koji nalaže iskrenost. U đātaki br. 128, rođen kao štakor, ubija šakala, što je protivno najvišem buddhističkom propisu koji brani ubijanje. U ubijanje ili namjerno ozljeđivanje drugoga bića Bodhisatta je upleten u ukupno jedanaest đātaka (Jones 1979: 63 u Appleton 2010: 29, bilj. 14). U pojedinim je dātakama (npr. br. 38, 279 i 318) pljačkaš, što se kosi sa zabranom uzimanja onoga što čovjeku ne pripada. U đātaki je br. 251 asket koji, ugledavši golu ženu, gubi prisebnost i moć levitacije. Time krši jedno od pet laičkih i deset redovničkih propisa. ${ }^{13} \mathrm{Na}$ isti se propis Bodhisatta oglušuje i u đātaki br. 431, u kojoj se zaljubljuje u udanu ženu i provodi s njom noć. Bodhisatta je prikazan i kao goli isposnik (br. 94). Intenzivno trapljenje i mučenje tijela nerijetko se kritizira u buddhističkim tekstovima te je shvaćeno kao nedostatak ispravnoga razumijevanja (sammā ditțhi). Bodhisatta je i brāhman učen u trima Vedama i osamnaest vedskih znanosti (br. 61 i 130), što se, iz buddhističke perspektive, također može smatrati herezom. Đātaka br. 174 primjer je pak Bodhisattine naivnosti ili neiskusnosti. Tu je Bodhisatta brāhmaṇ koji je došao na bunar po vodu. U blizini se našao i žedan majmun koji je zatražio da ga napoji. Nakon što mu je Bodhisatta zagrabio i dao vode, majmun se počeo kreveljiti i rugati mu se, pa ga je Bodhisatta, iznenađen takvim ponašanjem, prekorio zbog nezahvalnosti. Nimalo posramljen, majmun je rekao (i učinio) otprilike sljedeće:

Ti misliš da je to sve što mogu napraviti? Prije negoli odem, još ću ti nešto ispustiti na glavu. Izrekao je u stihu:

\footnotetext{
13 Opširnije u Lamotte 1976: 53-55, 70.
} 
V. Grabovac, Buddha u prvom i trećem pripovjednom licu (115-134)

"Umjetnost riječi" LXIV (2020) • 1-2 • Zagreb • siječanj - lipanj

Tko je ikada vidio il’ čuo za majmuna koji se pristojno ponaša?

Bacit ću ti sada još i izmet na glavu, jer takva je upravo narav naša!

Čuvši te riječi, Bodhisatta je krenuo da ode. U tom ga je trenutku majmun, sjedeći na grani, pogodio svojim izmetom u glavu, nakon čega je, kreveljeći se, pobjegao u šumu. Bodhisatta se oprao i otišao svojim putem. ${ }^{14}$

\subsection{ZAKLJUČAK ĐĀTAKE}

Iako najčešće sveden na jednu ili dvije rečenice, zaključak ima bitnu ulogu. U zaključku se, naime, ponovno javlja lik Buddhe koji, povezujući likove iz priče iz prošlosti s likovima iz priče iz sadašnjosti, vraća đātaku na njezino ishodište, u priču iz sadašnjosti. Poistovjećujući se s jednim od likova priče iz prošlosti, Buddha potvrđuje da je upravo on, kao Bodhisatta, sudjelovao u iznesenom događaju. Za razliku od priče iz sadašnjosti i priče iz prošlosti koje su iznesene u trećem pripovjednom licu, u zaključku se dātake, pri poistovjećivanju likova, sustavno i bez iznimke rabi prvo pripovjedno lice. Kao primjer može se navesti zaključak đātake iz koje je preuzet ranije naveden ulomak:

Nakon što je završio pripovijest, Učitelj reče: "Nije Devadatta takav prvi put. ${ }^{15}$ On ni prije nije znao prepoznati ljubaznost koju mu učinih". Potom je povezao rodenja: "Devadatta je onomad bio majmun, a ja sam bio onaj brāhmaṇ". ${ }^{16}$

Inzistiranje na dosljednoj uporabi zamjenice $j a$ ne mora nužno proizlaziti iz nepostojanja neupravnoga govora u indijskim jezicima, iako je takvo jednostavno objašnjenje vrlo uvjerljivo, već može biti protumačeno i kao

${ }^{14}$ ĐA 2. 71: "Taṃ sutvā so mittadūbhimakkațo "tvaṃ ettaken; eva tạ̣ nițțhitan ti saññam karosi, idāni te sīse vaccam pātetvā gamissāmīti” vatvā dutiyam gātham āha: Ko te suto vā diț̣ho vā sīlavā nāma makkaṭo, idāni kho tạ̣ ūhacca, esā amhāka dhammatā ti. Taṃ sutvā Bodhisatto uțṭhāya gantuṃ ārabhi. Makkaṭo tạ̣ khaṇañ ñeva uppatitvā sākhāya nisīditvā olambakạ̣ otārento viya tassa sīse vaccaṃ pātetvā viravanto vanasaṇụaṃ pāvisi. Bodhisatto nahātvā agamāsi."

${ }^{15}$ Povod za đātaku, a koji se nalazi u priči iz sadašnjosti, razgovor je redovnika koji se čude Devadattinoj nezahvalnosti i prijetvornosti. Devadatta, Buddhin bratić i član redovničke zajednice, u buddhističkim je tekstovima opisan kao Buddhin neprijatelj i podrivač sloge među redovnicima. U dātakama mu se uvijek pripisuju negativne osobine. V. i Appleton 2019.

${ }^{16}$ ĐA 2. 72: "Satthā 'na bhikkhave idān; eva Devadatto, pubbe pi mayā katạ̣ guṇaṃ na jānāti yevā’ ti vatvā imaṃ desanaṃ āharitvā jātakaṃ samodhānesi: 'Tadā makkaṭo Devadatto ahosi, brāhmaṇo pana aham evā' 'ti." 
svjestan odabir autora/kompilatora đātaka. O tom će biti riječi u sljedećem poglavlju.

\section{JE LI BUDDHA BODHISATTA?}

\subsection{BUDDHA JEST BODHISATTA}

Sve đātake sadrže zaključak u kojem se Buddha poistovjećuje s njihovim protagonistom (“ja sam bio onaj brāhmaṇ”), što ne ostavlja mjesta sumnji da su pripovjedač Buddha i protagonist đātake Bodhisatta identični. Jasno sjećanje na svoje prijašnje egzistencije Buddha je, prema predaji, stekao u noći Probuđenja:

I onda, kada je moj usredotočeni um postao pročišćen, jasan, čist, nezakrčen, pokoran, spretan, siguran i staložen, usmjerio sam [ga] prema spoznaji sjećanja na ranije živote. Sjetio sam se tada mnogih i različitih ranijih života [...]. Tada sam se tako zvao, bio takva podrijetla, takva položaja, takve ishrane, 122 takvo je bilo moje iskustvo sreće i tuge, takva je bila duljina moga života, potom svršetak života. Ponovno sam se rodio i tada sam se tako zvao, bio takva podrijetla, takva položaja, takve ishrane, takvo je bilo moje iskustvo sreće i tuge, takva je bila duljina moga života, potom svršetak života i rođenje u ovom životu. Sjetio sam se, dakle, raznolikih ranijih života s njihovim pojedinostima i detaljima. ${ }^{17}$

Buddhino poznavanje vlastitih prijašnjih egzistencija utemeljeno je u prvome znanju, dok je poznavanje prijašnjih egzistencija drugih osoba utemeljeno u drugome od ukupno triju znanja koja je stekao u noći Probuđenja. ${ }^{18}$ Ta su znanja, kako piše Reynolds, pružila čvrst epistemološki temelj za vjerodostojnost pripovijesti o njegovim prijašnjim egzistencijama (Reynolds 1998: 21).

Pripovijedanje u prvom licu, kako ističe Grdešić, sugerira nadalje i bliskost komunikacije (Grdešić 2015: 114), a na značenje uporabe prvoga pripovjednoga lica u iznošenju Buddhina posljednjega života u pālijskim

${ }^{17}$ Maddhimanikāya 1.22 (Maddhimanikāya, kanonska zbirka "srednje dugih" Buddhinih izlaganja). Izvorni tekst nije dan zbog duljine ulomka. Izvornik u Trenckner (izd.) 1888. Engleski prijevod u Ñānamoli i Bodhi 1995: 105.

${ }^{18}$ Pod trećim se znanjem podrazumijeva jasna svijest o uništenju ili nestanku svih kvarnosti (pāli āsava, skt. āśrava). Opširnije o sadržaju Probuđenja u Nakamura 2002: 185 i d. 
kanonskim tekstovima naspram uporabe trećega lica ukazuje i Sarah Shaw u svome eseju "And that was I":

Čini nam se da su rani redaktori, kao i sam Buddha, željeli da u suttama ${ }^{19}$ on bude prikazan kao inspirativan, ali ipak "tipski lik" koji samo ilustrira buddhinstvo. $U$ tu se svrhu najčešće rabi treće pripovjedno lice. Međutim, s vremena na vrijeme željeli su ukazati i na izravnost osobnoga iskustva, na neke osobine svojstvene Gotami Buddhi i općenito pokazati da se on, iako je dosegao izvanredan status, ne razlikuje mnogo od drugih. Tu je sporadična uporaba prvoga lica pri opisivanju ranijih događaja znakovita. (Shaw 2010: 30)

Bronkhorst također bilježi opušteno i prijateljsko ozračje koje povremeno prožima opise razgovora Buddhe i njegovih učenika (Bronkhorst 1993: 25 u Shaw 2010: 32), a ono se posebno osjeća u đātakama čija priča iz sadašnjosti donosi povod za Buddhino izlaganje nekog događaja iz svojih prijašnjih egzistencija. Činjenica da se redovnici ne ustručavaju ili ne srame pred uzvišenim učiteljem iznijeti sadržaj svojih nerijetko sasvim ovosvjetovnih, a ponekad čaki banalnih problema svjedoči o njihovoj opuštenosti i bliskosti s Buddhom. Ona odražava i potpuno povjerenje redovnika (i laika) u Buddhinu sveobuhvatnu mudrost i upućenost u pitanja ne samo duhovne već i sasvim ovosvjetovne i općeljudske naravi. Ipak, Buddha nije mogao u jednome životu steći iskustvo i znanje o raznolikim situacijama i problemima u kojima se zatječu "obična" bića. Njegov je životopis dobro poznat svima koji imaju priliku čuti đātaku, a u njemu nema mjesta za "obične" događaje. Od rođenja obilježen znakovima savršenstva, pažljivo i brižno odgajan i štićen od svake patnje i nelagode, otišao je u beskućništvo i nadljudskim tjelesnim i mentalnim naporom dosegao Probuđenje. Savršeni Buddha ne može iz osobnoga iskustva znati kako se osjeća redovnik koji ne može odoljeti ukusnoj hrani, trgovac koji se sprema na opasan put ili čovjek kojemu je umro sin. Međutim, proživjevši na stotine različitih egzistencija kao Bodhisatta, stekao je ta iskustva i time autoritet da o njima govori kako bi i ostalim nesavršenim bićima "rasvijetlio put". $7 a$ pokazuje da Buddha uistinu posjeduje sveobuhvatno znanje te da razumije raznolikost patnje i ograničenja ljudskoga iskustva zato što ih je i sam iskusio. Buddhino neizmjerno suosjećanje spram svih bića, a koje se vrlo često ističe kao jedna od njegovih najvažnijih osobina i motiv za propovijedanje i poučavanje, prikazano je kao utemeljeno u osobnim iskustvima. Mišljenja sam da uporaba zamjenice $j a$ u zaključku nije slučajna. Ona je tu da izvan svake sumnje potvrdi identitet Buddhe i Bodhisatte i uvjeri slušatelja da Buddha,

${ }^{19}$ Sutta (skt. sūtra), Buddhina propovijed, prozna književna vrsta. 
iako je u trenutku pripovijedanja đātake u cijelosti oslobođen patnje, može ne samo razumjeti tuđu patnju i suosjećati već i pomoći drugima da ju preko njegova iskustva nadiđu. Budući da su savršenstva u darežljivosti, hrabrosti, mudrosti itd. shvaćena kao preduvjet za postizanje Probuđenja, zamjenicom ja potvrđuje se i da sva u prijašnjim egzistencijama stečena savršenstva pripadaju upravo Buddhi koji je njihovim predanim prakticiranjem stekao uvjete koji su ga predodredili za Probudenje.

\subsection{BUDDHA JEST I NIJE BODHISATTA}

Sve su priče iz prošlosti, točnije đātake u užem smislu, ispričane u trećem pripovjednom licu, a ponekad se do samoga kraja đātake može samo pretpostavljati iza kojega se lika krije Bodhisatta. Pripovijedanje u trećem licu omogućuje ne samo svojevrsni odmak od priče iz sadašnjosti u kojoj se navodi povod za priču iz prošlosti već i odmak od "nesavršenoga" Bodhisatte. Naime, kako je u grubim crtama pokazano, Bodhisatta se ponekad rađa kao životinja, ${ }^{20}$ njegova je mudrost uglavnom praktične naravi, a đātake opisuju

124 ne samo hvalevrijedna Bodhisattina djela već nerijetko i njegove moralno upitne ili čak neprihvatljive postupke koji bi, u slučaju da je priča iz prošlosti ispričana u prvome licu, nedvojbeno narušili sliku savršenoga Buddhe. Takvo shvaćanje potkrjepljuje zapažanje Naomi Appleton koja ukazuje na osobitost đātaka sadržanih u kanonskoj Carìyapitaki, a koje su u cijelosti iznesene u prvome licu: "Čini se da u Ćarìyapițaki postoji pokušaj da se Bodhisatta udalji od moralno upitnih ili beznačajnih djela kakva se susreću u ĐA-i, zbog čega su iz teksta uklonjeni čitavi odlomci" (Appleton 2015: 6). Shaw također primjećuje da pripovijedanje u trećem licu omogućuje Buddhi da opisuje ono u čemu nije mogao sudjelovati u posljednjem životu (Shaw 2010: 37). Obje autorice potvrđuju da balansiranje između uporabe prvoga i trećega pripovjednoga lica potvrđuje Buddhinu (u)savršenost i sveznanje, ali da istovremeno stvara distancu između savršenoga Buddhe i ne(u)savršenoga Bodhisatte. Bodhisatta je, podsjećam, biće koje je tek na putu prema Probuđenju. Drugim riječima, Bodhisatta na svome dugom putu prema Probuđenju povremeno griješi, donosi krive procjene i čini pogrešna djela. Autori/kompilatori đātaka ne ustručavaju se pokazati da je Bodhisatta nesavršen i ne idealiziraju biće koje,

${ }^{20}$ Rođenje u obličju životinje smatra se "nižim" rođenjem te je shvaćeno kao posljedica lošega ili pogrešnog djelovanja u nekoj od prijašnjih egzistencija. Ipak, rođenje u obličju životinje nije prepreka dobrom ili ispravnom djelovanju. To potvrđuju i brojne đātake u kojima Bodhisatta, rođen u tijelu životinje, prakticira savršenstva i ukazuje na ispravan način djelovanja. 
budući da još uvijek nije doseglo Probuđenje, i ne može biti savršeno. Ipak, dosljednom izmjenom zamjenica $j a$ i on uspijevaju povući granicu između Bodhisatte i Buddhe i tako ne narušiti status i autoritet Buddhe u trenutku njegova pripovijedanja. Da je navedeni prijevod ulomka đātake, a koja završava slikom Bodhisatte uprljanoga majmunovim izmetom, bio iznesen u prvome licu, odnosno da nema granice između priče iz prošlosti u trećem licu i zaključka u prvome pripovjednome licu koji čitatelja/slušatelja vraća u "sadašnjost", đātaka bi ne samo izgubila svoj smisao (istaknuti razliku između bića na putu i bića koje je došlo do svoga konačnog odredišta tj. Probuđenja) ${ }^{21}$ već bi imala i difamantan učinak.

Opreka ja/on može se prenijeti i u polje buddhističke doktrine kako bi se ponudio još jedan mogući razlog za uvjerenje da izmjena pripovjednih lica nije slučajna, već da na vrlo suptilan način ilustrira ili odražava i neka od temeljnih buddhističkih učenja. Započnimo s naukom o ne-sopstvu (pāli anattā, sanskrt anätman). Taj je nauk jedan od temelja buddhističke misli, a njime se tvrdi da ne postoji ništa što bi se moglo nazvati trajnim i nepromjenjivim sopstvom. ${ }^{22}$ Buddhistički nas tekstovi neprestano podsjećaju da su svi fenomeni postojanja obilježeni trima karakteristikama: podložni su promjeni (anićća, skt. anitya), prožeti su patnjom (dukkba, skt. duḅkba) i lišeni su sopstva (anattā, skt. anātmaka). Bića nisu nedjeljive jedinice, već ukupan zbroj pet "nakupina" (khandha, skt. skandha), a to su: ${ }^{23}$ tjelesnost (rüpa), osjećanja

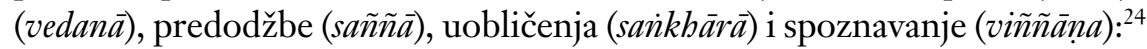

[...] ono što se konvencionalno naziva "osobom" dade se razumjeti kroz prizmu pet nakupina. Budući da bića nisu ništa drugo do amalgam fenomena koji su uvijek iznova podložni promjeni, njihova se ukupnost ne smije pogrešno razumjeti kao nepromjenjiv entitet. (Boisvert 1995: 4) 25

${ }^{21}$ V. Appleton 2010: 51.

${ }^{22}$ Oldenberg piše: "U bezbrojnim govorima prikazuje se kako ni kod jednog živog bića ne postoji duhovno nešto što kao mirni pol opstoji u struji zbivanja, poput 'duše' drugih indijskih i ne-indijskih sistema. U uvijek novim izrazima Buddha razjašnjava svojim učenicima da se nigdje u svijetu ne može naći neko 'attā' (sanskrt: ātman). Ta riječ 'sopstvo' često ne označava samo dušu kao u upanišadama, nego općenito svaku supstanciju koja posjeduje samostalan i stoga od drugog nezavisan, vječni bitak, koji nije podložan prolaznosti te, otud, ni patnji" (Oldenberg 2007: 388-389).

${ }^{23}$ Iscrpnu studiju o pet khandhi i njihovu mjestu u buddhističkoj filozofiji i psihologiji nudi Boisvert 1995. Čitatelja upućujem i na kraći prikaz u Oldenberg 2007: 385 i d.

${ }^{24}$ Ovdje slijedim Mikulićev prijevod u Oldenberg 2007: 201. Detaljnije o svakoj khandhi u Oldenberg 2007: 386-388 i Boisvert 1995.

25 Tvrdnja se može potkrijepiti i ulomkom iz kanonskoga teksta sadržanoga u Maddhimanikāyi: "Ovako Blaženi, o, Aggivessana, poučava svoje učenike i ovako je pouka 
Međutim, ako ni jedna od pet nakupina koje sačinjavaju ono što nazivamo osobom nije trajna, već su sve nestalne, promjenjive i lišene sopstva, što je onda to što prelazi iz jedne egzistencije u drugu neprestano se i iznova rađajući i umirući? Valja odmah istaknuti da bi opširniji ili precizniji prikaz toga problema zahtijevao mnogo više mjesta negoli je to ovdje moguće, pa će se proces prerađanja opisati samo u osnovnim crtama. Prerađanje ili prelazak iz jedne egzistencije u sljedeću odvija se po utvrđenom slijedu razloženom u nauku o uvjetovanom (kauzalnom) postajanju, a koji stoji u samome središtu buddhističke misli. ${ }^{26}$ Ipak, da ne ulazimo dublje u sadržaj toga nauka, za potrebe je ovoga rada dovoljno reći da je svako (novo) rođenje shvaćeno kao rezultat djelovanja (kamma, skt. karman) u prijašnjim egzistencijama. ${ }^{27}$ Svako (svjesno) djelovanje ili čin ima svoju posljedicu ili "plod" koji će sazreti ili u trenutnom životu ili u nekoj od sljedećih egzistencija. Ovisno o tome je li djelovanje dobro (kusala, skt. kuśala) ili loše (akusala, skt. akuśala), ono će dovesti do ploda, odnosno rezultirat će rođenjem u nekoj od pet mogućih "sudbina" ili svjetova (pañcagati): rođenje u paklu, među životinjama, među sablastima, među ljudima ili među nebesnicima. ${ }^{28}$ Sazrijevanje "ploda djelovanja" potaknuto je trovrsnom žeđi za postajanjem (taṇhāa, skt. tṛṣnā), 126 a koja je uzrok nastanka patnje i novoga ponovnog rođenja. ${ }^{29}$

Blaženoga često predstavljena njegovim učenicima: 'Redovnici, tjelesnost je nestalna, osjećanje je nestalno, predodžba je nestalna, uobličenja su nestalna, spoznajna je svijest nestalna. Redovnici, tjelesnost nije sopstvo, osjećanje nije sopstvo, predodžba nije sopstvo, uobličenja nisu sopstvo, spoznajna svijet nije sopstvo. Svi su fenomeni nestalni, ništa nije sopstvo'" (Maddhimanikāya 1. 228. Izvornik u Trenckner (izd.) 1888. Prijevod na engleski jezik u Ñānamoli i Bodhi 1995: 322). Prevedeni ulomak ilustrira ujedno i smisao prve od ukupno četiriju buddhističkih istina: "Ovo je, o redovnici, plemenita istina o patnji; rođenje je patnja, starost je patnja, bolest je patnja, smrt je patnja, sjedinjenost s nedragim je patnja, odvojenost od dragog je patnja, nepostizanje onoga što žudim patnja je, ukratko, pet predmeta hvatanja patnja je" (prijevod B. Mikulića u Oldenberg 2007: 199). Oldenberg objašnjava da se pod "hvatanjem" misli na hvatanje ili prianjanje uz pet činilaca postojanja odnosno uz pet kbandhi (Oldenberg 2007: 199, bilj. 3).

${ }^{26}$ Nauk o uvjetovanom (kauzalnom) postajanju naziva se pațiccasamuppāda, skt. pratītyasamutpāda. "Lanac" se uvjetovanoga postajanja sastoji od dvanaest "karika" od kojih je svaka uvjet nastanka sljedeće. Čitatelja ovdje upućujem na Lamotte 1976: 26-42, Oldenberg 2007: 211 i d., Wayman 1971, Boisvert 1995.

${ }^{27}$ Lamotte 1976: 33.

${ }^{28}$ Lamotte 1976: 31-33.

${ }^{29}$ Tvrdnju podupire druga buddhistička istina: "Ovo je, o redovnici, plemenita istina o nastanku patnje: to je žed koja vodi od jednog ponovnog rođenja do drugog ponovnog rođenja zajedno s radošću i požudom, koja nalazi radost sad ovdje sad ondje: žed za užitkom, žed za postajanjem, žeđ za prolaznim” (prijevod B. Mikulića u Oldenberg 2007: 211). 
U procesu prerađanja nakupine koje sačinjavaju osobu slikovito se rečeno rastaču, dok se nove nakupine, u ovisnosti o prijašnjim djelima i potaknute žeđi za postajanjem, preslaguju i uobličuju. Buddhisti su bili svjesni problema koji se javlja ako se prihvati tvrdnja o nestalnosti i propadljivosti svih sastavnica koje sačinjavaju ono što konvencijom nazivamo osobom. Ako se u trenutku smrti sve sastavnice rastave i rastoče, komu se mogu pripisati plodovi djelovanja začeti u prošlosti? Ulomak iz kanonskoga teksta nudi Buddhino rješenje:

Tada je neki brāhmaṇ prišao Blaženom i razmijenio s njim pozdrave. Pošto su se pozdravili i prozborili nekoliko uljudnih riječi, sjeo je taj brāhman na jednu stranu i upitao Blaženog: "Učitelju Gotama, kako? Je li onaj koji djeluje isti onaj koji ce iskusiti [plod djelovanja]?”

- "Onaj koji djeluje isti je onaj koji će iskusiti [plod djelovanja] - to je, brāhmane, jedna krajnost."

- "Je li onda, učitelju Gotama, onaj koji djeluje jedno, a onaj koji će iskusiti [plod djelovanja] drugo?"

- "Onaj koji djeluje je jedno, a onaj koji će iskusiti [plod djelovanja] je drugo

- to je, brāhmaṇe, druga krajnost. Ne priklanjajući se ni jednoj krajnosti,

Tathāgata ${ }^{30}$ poučava dhammu ${ }^{31}$ koja ide sredinom" $[\ldots]^{32}$

Ukratko, biće koje se (ponovno) rađa nije ni isto (sve sastavnice od kojih je bilo sačinjeno u prijašnjoj egzistenciji rastočile su se), ali nije ni posve različito od bića koje se prerodilo u nekom od pet mogućih svjetova jer su mu novo rođenje (pred)odredila njegova prijašnja djela.

Sagledamo li izmjenu pripovjednih lica u đātakama u svjetlu buddhističkoga shvaćanja ne-sopstva i razumijevanja procesa prerađanja, može se pretpostaviti da su dosljednom izmjenom zamjenica $j a$ i on autori/kompilatori đātaka nastojali povezati Buddhu s plodovima (ispravnih) djela u prijašnjim egzistencijama, ali i naglasiti istovremeno da Buddha nije onaj isti on koji je ta djela činio. ${ }^{33}$ Da je i priča iz prošlosti iznesena u prvome licu, ne bi postojala granica između nje i priče iz sadašnjosti, odnosno granica između Buddhe i Bodhisatte. Time bi se nedvojbeno sugeriralo da su Buddha i Bodhisatta

${ }^{30}$ Tathāgata, dosl. tako otišao ili tako došao, jedan od Buddhinih epiteta.

${ }^{31}$ Skt. dharma. Imenica dhamma/dharma ima mnoga značenja, a u ovome se kontekstu može razumjeti kao nauk. Za moguća značenja v. Monier-Williams 1999: 510.

32 Samyuttanikāya 2.76 (Samyuttanikāya, kanonska zbirka Buddhinih izlaganja razvrstanih u skupine). Izvornik u Feer (izd.) 1888. Engleski prijevod u Bodhi 2000: 583.

${ }^{33}$ Strong također naglašava da su buddhisti bili svjesni kako se linearnim protezanjem Buddhina životopisa u prošlost povećava rizik za shvaćanje prema kojem postoji neko sopstvo koje prelazi iz jedne u drugu egzistenciju (Strong 1997: 114). 
jedno te isto, a to bi proturječilo nauku o nepostojanju trajnoga sopstva. S druge strane, da je i zaključak đātake iznesen u trećem licu, izgubio bi se ne samo osjećaj da je đātaku ispričao sam Buddha i da je ona time Buddhina riječ (buddhavaćana) već bi se, riječima Appleton, izgubio i osjećaj "svjesne ravnoteže između povezanosti i udaljenosti" (Appleton 2015: 7). ${ }^{34}$ Ta ravnoteža između povezanosti s plodovima djelovanja i udaljenosti od bića koje je djelovalo u nekoj od prijašnjih egzistencija, a koju đātake uspijevaju održati upravo stalnom i dosljednom izmjenom zamjenica ja i on, možda se može protumačiti kao odraz buddhističkoga stava da "učenik mora naučiti da nigdje ne egzistira ništa postojano, nego da stalno postoje samo procesi strujanja" (Oldenberg 2007: 388-389).

\subsection{BUDDHA NIJE (NUŽNO) BODHISATTA}

$\mathrm{Na}$ ovome bih mjestu otišla korak dalje i, slijedeći neka od Bettelheimovih opažanja vezanih uz bajke, pokušala ukazati na mogućnost da đātake, usredotočimo li se samo na njihov tematsko-moralni sadržaj, ostavljaju mjesta i za interpretaciju prema kojoj Bodhisatta ne mora nužno biti shvaćen kao Buddha u nekoj od svojih prijašnjih egzistencija. Naime, odstranimo li priču iz sadašnjosti u kojoj se pojavljuje lik pripovjedača Buddhe i zaključak u kojem se Buddha poistovjećuje s nekim od likova iz priče o prošlosti, dobit ćemo sasvim samostalnu pripovijest koja nalikuje na bilo koju poučnu priču ili bajku. Imajući na umu da brojne đātake u svome izvornome obliku nisu bile buddhističke i da se u njima nije pojavljivao lik Buddhe/Bodhisatte, možemo ih promatrati i kao pripovijesti u kojima se susreću ne isključivo buddhističke, već i univerzalne i općeljudske teme i motivi kao što su mudrost, glupost, ljubav, zloba, pravda i nepravda, smrt, ljubomora, hrabrost, požuda, iskrenost, tuga, suosjećanje, zajedništvo itd. Iako sve đātake nisu bajke, na tematskome i moralnome planu te pripovijesti dijele s bajkama neka zajednička obilježja. Primjerice, najčešća uvodna rečenica priče iz prošlosti "Jednom davno, kada je Brahmadatta bio kralj Benaresa...", a kojom se pripovijedani događaji smještaju u neku daleku, legendarnu prošlost, snažno podsjeća na početak bajki. Pišući o početku većine bajki (Nekada davno; u jednoj zemlji; u vrijeme kada su životinje još govorile...), Bettelheim je zaključio da "takvi početci nagovješćuju kako ono što slijedi nije od danas ni

${ }^{34}$ Appleton se na ovome mjestu osvrće na Āryaśurinu zbirku đātaka Đātakamālāā (3-4 st.) u kojoj su sve đātake ispričane u trećem pripovjednom licu i u kojima nedostaje lik pripovjedača Buddhe. 
tu što poznajemo. Ova namjerna neodređenost u početku bajki simbolički kazuje kako napuštamo zbiljski svijet obične stvarnosti" (Bettelheim 2004: 61). ${ }^{35}$ Nadalje, likovi koji se pojavljuju u dātakama, uključujući i Bodhisattu, vrlo često nemaju osobno ime, a ponekad imaju imena koja samo ukazuju na neko tjelesno obilježje, karakternu crtu ili slično, što također podsjeća na postupak primjenjivan u bajkama (v. Bettelheim 2004: 43). ${ }^{36}$ Također, likovi u bajkama, kako piše Bettelheim, nikada nisu i dobri i loši u isto vrijeme: jedan je brat glup, drugi pametan; jedna je sestra lijepa i marljiva, druga ružna i lijena (Bettelheim 2004: 18). Isto stanje zatječemo i u brojnim dātakama: jedan je jelen suosjećajan i požrtvovan, drugi sebičan i okrutan (br. 12); jedan je rizničar pohlepan i podmitljiv, drugi (Bodhisatta) pošten i nepodmitljiv (br. 5). Za bajke je karakteristično da je u njima egzistencijalna dilema ili kriza predstavljena jasno i koncizno (Bettelhiem 2004: 17). Đātake također iznose u priči iz sadašnjosti jasan povod za priču iz prošlosti. Priča iz prošlosti ili đātaka u užem smislu odgovor je na konkretno pitanje ili dvojbu: kako je moguće da se žena iz ugledne obitelji zaljubi u grbavca i pobjegne $s$ njim (br. 232), zašto je neki redovnik okrutan i pun mržnje (br. 222), kako se nositi s gubitkom bogatstva i ugleda (br. 339), kako prihvatiti da nam je preminuo netko blizak (br. 372) i tako dalje. Činjenica da Bodhisatta ponekad krši pravila, da se služi lukavstvom, laži i prijevarom kako bi ostvario neki cilj također podsjeća na postupke pojedinih likova u bajkama. Kako tvrdi Bettelheim, opisana nemoralna djela ne grade karakter ukazivanjem na izbor između dobroga i lošega, već davanjem nade da čak i najslabiji mogu uspjeti u životu. U bajkama, zaključuje Bettelheim, tema nije moral, već potvrda da čovjek može uspjeti i da su porazi i poteškoće s kojima se susreće također važan i sastavni dio ljudske egzistencije (Bettelheim 2004: 18-19). Moralno upitna Bodhisattina djela također pružaju nadu da nas krivi izbori i krive odluke koje donosimo, iako, naravno, imaju svoju karmičku posljedicu, ne određuju apsolutno i za "sva vremena". Put je, prema buddhističkome shvaćanju, dug i uvijek nam ostaje mogućnost da učimo, stječemo mudrost i polako napredujemo. Zaključak đātake služi upravo tomu da se čitatelj ili slušatelj podsjeti da je pripovijest iznio savršeni i besprijekorni Buddha koji je i sam nekada bio nesavršen i povremeno podložan krivim stavovima i odlukama.

${ }^{35}$ Appleton piše kako je upravo ta neodređenost mjesta i vremena u pričama iz prošlosti omogućila da se đatake, tijekom širenja buddhističkoga nauka, prilagode i udomaće na novim područjima (Appleton 2007: 120).

${ }^{36}$ Npr. imena dvojice redovnika u đātaki br. 4 jesu Stariji put i Mlađi put s obzirom na to da ih je majka rodila dok je bila na putu prema roditeljskoj kući. 
Bajke su već odavno u psihijatriji i psihoanalizi prepoznate kao jedno od sredstava liječenja. Sigmund Freud, Carl G. Jung i Julius Heuscher samo su neki od autora koji su ukazali na značenje bajki u oslovljavanju i osvještavanju čovjekovih nesvjesnih mehanizama (v. Wallace i dr. 2018: 114), a na ulogu koju đātake mogu imati u psihoanalizi ukazao je i Martin Wickramasinghe u svojim knjigama The Buddhist Fataka Stories and the Russian Novel (1956) i Jathaka Katha Vimasuma (1968). Ukratko, kroz lik Bodhisatte, njegove karakterne osobine i događaje u kojima je sudjelovao u đātakama se predstavljaju raznoliki mentalni fenomeni i egzistencijalni problemi koje čak i danas možemo prepoznati kao općeljudske te se nudi model za njihovo osvještavanje i razrješavanje. Ne čudi stoga da se u zaključku velikoga broja đātaka tvrdi da su redovnici, a koji su u priči iz sadašnjosti imali neki problem, nedoumicu ili su pak moralno posrnuli, po završetku pripovijesti razumjeli pouku i dosegli "plod što ga donosi stupanje na put" (sotāpattiphale patitțhahimsu). ${ }^{37}$ Shvatimo li priče iz prošlosti kao buddhistički odgovor na općeljudska egzistencijalna pitanja, možemo pretpostaviti da smještanjem radnje u neku daleku, legendarnu prošlost i suptilnim zamagljivanjem Bodhisattina identiteta đātake, kao i bajke, nude mogućnost da 130 problem, pitanje ili neku situaciju sagledamo sa sigurne udaljenosti i da prateći postupke njihovih protagonista dođemo, kao i redovnici iz priče iz sadašnjosti, do odgovora na vlastito pitanje. Bodhisatta, kao uostalom i svaki drugi lik iz priče iz prošlosti, postaje tako bilo koji on - trgovac pred kojim je težak put, čovjek koji sumnja u vjernost svoje supruge, sin koji se brine za ostarjele roditelje, roditelj kojemu je umrlo dijete, učitelj pred kojim je golema odgovornost, varalica, ubojica, ljubavnik udane žene ili naprosto čovjek koji je usprkos dobroj namjeri izašao iz neke situacije "umrljan majmunovim izmetom". ${ }^{38}$

\section{ZAKLJUČAK}

Buddhin se posljednji život nerijetko u buddhističkoj književnosti prikazuje kao preslika temeljnoga predloška, odnosno kao ilustracija životnoga puta

${ }^{37}$ Vidi, primjerice, zaključak Mālutađātake (br. 7), ĐA 1. 165.

${ }^{38}$ Najveći je broj đātaka iznesen pred muškim članovima redovničke zajednice, a postoje i one, kako je ranije rečeno, koje su upućene muškim članovima zajednice laičkih sljedbenika. ĐA ne sadrži đātake upućene ženama, ni redovnicama ni ženama-laicima. Iako postoje đātake, preciznije priče iz prošlosti, u kojima se javljaju ženski likovi kao protagonisti (npr. br. 194, 201, 358), njihov je broj znatno manji. 
koji dijele svi buddhe. ${ }^{39}$ Kao što Buddha nikako nije mogao biti rođen u obitelji trgovaca ili kao pripadnik najniže kaste, jer je pravilo da se svaki buddha rađa u obitelji brāhmaṇa ili kšatriya, tako su i ostali ključni trenutci jasno i unaprijed određeni. U njemu nema odstupanja od jasno zacrtanih pravila, pa se taj životopis, izuzmu li se detalji kao što su primjerice vrsta stabla pod kojim doživljava Probuđenje, broj učenika ili duljina života, odnosi na svakoga buddhu. Gotama je Buddha tako shvaćen kao jedan od mnogih buddha koji su se pojavili prije njega i koji će se pojaviti nakon njega i od kojih svaki slijedi isti životni put. Taj je životopis u buddhističkim tekstovima u najvećoj mjeri iznesen u trećem licu. Đātake, pripovijesti o egzistencijama koje su prethodile njegovu posljednjem rođenju, također su shvaćene kao dio Buddhina životopisa, ali u njima nalazimo sve ono što inače ne bi moglo stati u njegov životopis omeđen rođenjem i smrću. Da bi se u njima opisani događaji zaista pripisali Buddhinu životopisu, iskorišteno je prvo pripovjedno lice. Zamjenicom $j a$ u zaključku đātake Buddha prestaje biti "tipski lik", u đātakama opisana iskustva nesumnjivo su njegova, a time mu je životopis postao osoban i jedinstven. Također, zamjenicom se $j a$ potvrđuje da su Buddhino Probuđenje u njegovoj posljednjoj egzistenciji kao i sva njegova savršenstva u vrlinama plod njegovih prijašnjih (ispravnih) djelovanja. Time se opravdava i nauk o sazrijevanju ploda djelovanja ili uvjerenje da svaki čin ima svoju posljedicu koja se može očitovati ili u trenutnoj ili u nekoj od budućih egzistencija. S druge strane, uporabom se trećeg pripovjednog lica u priči iz prošlosti stvara ne samo nužan odmak od raznolikih (i nerijetko moralno upitnih) Buddhinih postupaka već se, možebitno, suptilno ilustrira nauk o nepostojanju trajnoga sopstva ili, drugim riječima, o nepostojanju ičega što bi u neizmijenjenom obliku moglo prelaziti iz jedne egzistencije u drugu. Dosljednom izmjenom zamjenica $j a$ i on sugerira se, u skladu s buddhističkim učenjem, da Buddha i Bodhisatta nisu sasvim jedno te isto. Također, uporabom se zamjenice on omogućuje da događaji iz Buddhine prošlosti postanu svojevrsni predložak za djelovanje ili ilustracija sitnih odsječaka životnoga puta s kojima se mogu poistovjetiti ili koje mogu iskusiti sva bića.

${ }^{39} \mathrm{U}$ theravādskoj je tradiciji Gotama Buddha shvaćen kao sedmi ili, prema djelima kasnijega postanka, dvadeset peti buddha koji se pojavio u svijetu. Opširnije o "lozi buddha" u Reynolds 1997: 24-30. 
V. Grabovac, Buddha u prvom i trećem pripovjednom licu (115-134)

"Umjetnost riječi" LXIV (2020) • 1-2 • Zagreb • siječanj - lipanj

\section{LITERATURA}

Appleton, Naomi. 2007. "A place for the Bodhisatta: The local and the universal in jātaka stories”, U: Acta Orientalia Vilnensia 8 (1): 109-122, doi: 10.15388/ AOV.2007.1.3748.

Appleton, Naomi. 2010. Fātaka Stories in Theravāda Buddhism. Narrating the Bodhisatta Path. London/New York: Routledge.

Appleton, Naomi. 2015. "The Buddha as Storyteller: The dialogical setting of Jātaka stories". U: Dialogue in Early South Asian Religions: Hindu, Buddhist and Jain Traditions. Ur. L. Patton i B. Black. Farnham: Ashgate Publishing: 99-112. Dostupno na: https://www.research.ed.ac.uk/portal/files/19324333/Buddha_as_Storyteller_ AFV.pdf (20. svibnja 2020)

Appleton, Naomi. 2019. "What Does It Mean To Be a Badly Behaved Animal? An Answer from the Devadatta Stories of the Pāli Jātakas". U: Religions 10/288, doi: $10.3390 /$ rel10040288.

Bettelheim, Bruno. 2004. Smisao i značenje bajki. Preveo s engleskog Vladimir Jakić. Cres: Poduzetništvo Jakić ([1975.], The Uses of Enchantement. The Meaning and Importance of Fairy Tales. New York: A. Knopf Inc.).

Bodhi, Bhikkhu. 2000. The connected discourses of the Buddha. A translation of the Samyutta Nikāya (prijevod s pālija). Boston: Wisdom Publications.

Boisvert, Mathieu. 1995. The Five Aggregates - Understanding Theravāda Psychology and Soteriology. Toronto, Ontario: Canadian Corporation for Studies in Religion.

Bronkhorst, Johannes. 2000. Two Traditions of Meditations in Ancient India. Delhi: Motilal Banarsidass [1993].

Dayal, Har. 1970. The Boddhisattva Doctrine in Buddhist Sanskrit Literature. Delhi/Patna/ Varanasi: Motilal Banarsidass [1932].

Fausbøll, Viggo (izd.). 1877-1896. The Jātaka, sv. 1-6. London: Pali Text Society. Dostupno na mrežnim stranicama GRETIL-a (2. siječnja 2020).

Feer, Leon. (izd.). 1888. Samyutta Nikaya of the Sutta Pitaka. Part II. Nidana Vagga. London: Pali Text Society. Dostupno na mrežnim stranicama GRETIL-a (20. svibnja 2020).

Grdešić, Maša. 2015. Uvod u naratologiju. Zagreb: Leykam International.

Jones, John G. 1979. Tales and Teachings of the Buddha: The Nidāna-kathā of the Fātakatțbakathā. London: George Allen and Unwin.

Katičić, Radoslav. 1973. Stara indijska književnost: sanskrtska, palijska i prakrtska. Zagreb: Nakladni zavod MH.

Lamotte, Étienne. 1988. History of Indian Buddhism: From the Origins to the Śaka Era (prijevod s francuskoga jezika: Sara Wobb-Boin). Louvain-la-Neuve.: Institut Orientaliste ([1958], Histoire du Bouddhisme Indien, des origines à l'ère G'aka. Louvain: Bibliothèque du Muséon).

Monier-Williams, Monier. 1999. Sanskrit English Dictionary. Delhi: Motilal Banarsidass ([1899], Oxford University Press).

Nakamura, Hajime. 2002. Gotama Buddha. A Biography Based on the Most Reliable Texts (I) (prijevod s japanskoga jezika: Gaynor Sekimori). Tokyo: Kosei Publishing Co [2000]. 
V. Grabovac, Buddha u prvom i trećem pripovjednom licu (115-134)

"Umjetnost riječi" LXIV (2020) • 1-2 • Zagreb • siječanj - lipanj

Nānamoli, Bhikkhu i Bhikkhu Bodhi. 1995. The Middle Length Discourses of the Buddha. A new Translation of the Majjhima Nikāya (prijevod s pālija). Kandy, Sri Lanka: Buddhist Publication Society.

Oldenberg, Hermann. 2007. Buddha. Njegov život, njegova zajednica, njegovo učenje (prijevod i predgovor s pojmovno-kritičkim bilješkama i bibliografskim dodatkom Borislav Mikulić). Zagreb: Demetra ([1881], Buddha Sein Leben, seine Lebre, seine Gemeinde. Berlin/Stuttgart: Cotta).

Olivelle, Patrick. 2009. The Pancatantra: the book of India's folk wisdom (prijevod sa sanskrta). Oxford/New York: Oxford University Press.

Reynolds, Frank. 1997. "Rebirth Traditions and the Lineages of Gotama. A Study in Theravāda Buddhology". U: Sacred biography in the Buddhist Traditions of South and Southeast Asia. Ur. Juliane Schober. University of Hawaii Press: 19-39.

Rhys Davids, T. W. 1887. Buddhist birth-stories (fataka tales). The commentarial introduction entitled Nidana-Kathā; the story of the lineage (prijevod Fausbøllova izdanja pālijskoga teksta). London: G. Routledge.

Shaw, Sarah. 2010. "And That Was I. How Buddha Himself Creates a Path between Biography and Autobiography". U: Lives Lived, Lives Imagined. Ur. Linda Covill i dr. Boston: Wisdom Publications: 15-47.

Strong, John S. 1997. "A Family Quest: The Buddha, Yaśodharā, and Rāhula in the Mūlasarvāstivāda Vinaya”. U: Sacred biography in the Buddhist Traditions of South and Southeast Asia. Ur. Juliane Schober. University of Hawaii Press: 113-128.

Trenckner, Vilhelm (izd.). 1888. Majjbima-Nikaya, Suttantas 1-76 (sv. 1). London: Pali Text Society (pretisak: 1948, 1964, 1979). Dostupno na mrežnim stranicama GRETIL-a (20. svibnja 2020)

Wallace, Ryan i dr. 2018. "Fairy Tales and Psychiatry: a Psychiatry Residency's Experience Using Fairy Tales and Related Literary Forms to Highlight Theoretical and Clinical Concepts in Childhood Development". U: Academic Psychiatry 43: 114-118, doi:10.1007/s40596-018-0968-5.

Wayman, Alex. 1971. "Buddhist Dependent Origination". U: History of Religions 10, 3: 185-203, doi: 10.1086/462628.

Wickramasinghe, Martin. 1956. The Buddhist Jataka Stories and the Russian Novel. Colombo, Sri Lanka: The Associated Newspapers of Ceylon Ltd.

Wickramasinghe, Martin. 1968. Jathaka Katha Vimasuma. Colombo: M. D. Gunasena.

\section{Prijevod dātaka na engleski jezik}

Internet Sacred Text Archive. Dostupno na: https://www.sacred-texts.com/bud/index. htm (8. listopada 2020) 
V. Grabovac, Buddha u prvom i trećem pripovjednom licu (115-134)

"Umjetnost riječi" LXIV (2020) • 1-2 • Zagreb • siječanj - lipanj

Abstract

\section{BUDDHA IN THE FIRST- AND THIRD-PERSON NARRATION}

The Jātakas tales about previous existences of Gotama Buddha are a voluminous and extremely popular part of Buddhist literature. Told, according to the Buddhist belief, by Gotama himself, the jātakas describe the path of the future Buddha (Bodhisatta) who, being reborn numerous times as human, animal or deity, gradually moves towards his last existence and Enlightenment. The paper aims to show a manner in which the shift between narrative voices simultaneously allows identification and distinction between Buddha and Bodhisatta (based on the research by Naomi Appleton and Sarah Shaw, and accompanied by additional explanations and illustrations). The Jātakas are presented in the light of the Buddhist doctrines of no-self and Buddhist interpretation of the rebirth-process. Also, it is suggested that the lasting popularity and the lure of the jātakas can be seen as rooted in their potency to serve as a kind of model for resolving various life-issues to which even a modern-day reader can relate to. The paper also aims to introduce Croatian readers to extremely diverse and numerous motifs and themes presented in the Pāli Jātaka collection.

134 Keywords: narrative 